\title{
What The CPA's Think About The Proposed Financial Statement Presentation
}

Stuart Shough, University of South Carolina Upstate, USA

\begin{abstract}
The Financial Accounting Standards Board and the International Accounting Standards Board jointly issued a Discussion Paper soliciting comments on a proposed financial statement presentation. This paper presents the results from 605 CPA's responses to selected questions asked in the Discussion Paper.
\end{abstract}

Keywords: FASB proposed financial statement presentation

\section{INTRODUCTION}

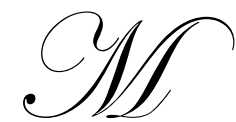

any users have expressed concerns that too many alternative types of presentations are allowed for financial statement presentation and that information in financial statements is highly aggregated and inconsistently presented, making it difficult to fully understand the relationship between the financial statements and the financial results of an entity.

In response, the Financial Accounting Standards Board and the International Accounting Standards Board jointly developed three objectives for financial statement presentation that state that information should be presented in the financial statements in a manner that portrays a cohesive financial picture of an entity's activities, disaggregates information so that it is useful in predicting an entity's future cash flows, and helps users assess an entity's liquidity and financial flexibility.

On October 16, 2008, the Boards jointly issued a Discussion Paper titled Preliminary Views on Financial Statement Presentation. The purpose of the Discussion Paper was to solicit comments on whether the proposed financial statement presentation would improve the usefulness of the information provided by the entity and help users in making decisions. Specific questions were included in the Discussion Paper for respondents to submit their comments in writing by April 14, 2009.

Subsequent to that, a survey of their opinions was made of CPAs. This paper presents the responses of 605 CPA's to selected questions drawn from the Discussion Paper.

\section{CLASSIFICATION SCHEME}

Exhibit 1 illustrates the proposed classification scheme for the financial statements. 
Exhibit 1

\begin{tabular}{|c|c|c|}
\hline $\begin{array}{c}\text { Statement of } \\
\text { Financial Position }\end{array}$ & $\begin{array}{c}\text { Statement of } \\
\text { Comprehensive Income }\end{array}$ & $\begin{array}{c}\text { Statement of } \\
\text { Cash Flows }\end{array}$ \\
\hline $\begin{array}{ll}\text { Business } \\
-\quad \text { Operating assets and liabilities } \\
-\quad \text { Investing assets and liabilities } \\
\end{array}$ & $\begin{array}{l}\text { Business } \\
\text { - } \quad \text { Operating income and expenses } \\
\text { - } \quad \text { Investing income and expenses }\end{array}$ & $\begin{array}{ll}\text { Business } \\
\text { - } & \text { Operating cash flows } \\
\text { - } & \text { Investing cash flows } \\
\end{array}$ \\
\hline $\begin{array}{l}\text { Financing } \\
\text { - } \quad \text { Financing assets } \\
\text { - } \quad \text { Financing liabilities } \\
\end{array}$ & $\begin{array}{l}\text { Financing } \\
\text { - } \quad \text { Financing asset income } \\
\text { - } \quad \text { Financing liability expenses } \\
\end{array}$ & $\begin{array}{ll}\text { Financing } \\
\text { - } \quad \text { Financing asset cash flows } \\
\text { - } \quad \text { Financing liability cash flows }\end{array}$ \\
\hline Income taxes & $\begin{array}{l}\text { Income taxes on continuing } \\
\text { operations (business and financing) }\end{array}$ & Income taxes \\
\hline Discontinued operations & $\begin{array}{l}\text { Discontinued operations, } \\
\text { net of tax }\end{array}$ & Discontinued operations \\
\hline Equity & $\begin{array}{l}\text { Other comprehensive income, } \\
\text { net of tax }\end{array}$ & Equity \\
\hline
\end{tabular}

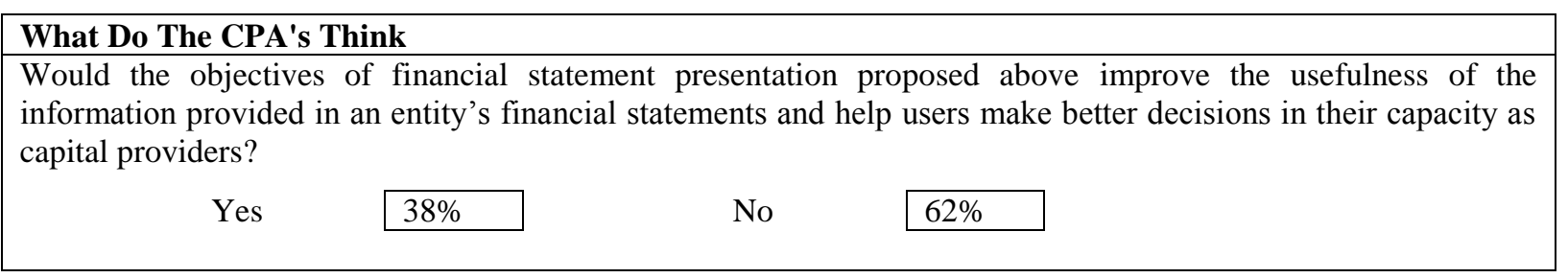

\section{STATEMENT OF FINANCIAL POSITION}

As can be observed in Exhibit 2, the Statement of Financial Position (Balance Sheet) would group data by major activities (operating, investing, and financing) not by assets, liabilities, and equity as at present.

The business activities section presents information about the way the entity creates value and the financing activities section presents information about the way it funds or finances those business activities.

\begin{tabular}{|l|}
\hline What Do The CPA's Think \\
\hline Would the separation of business activities from financing activities provide information that is more decision \\
useful than that provided in the financial statement formats used today? \\
Yes $\quad$ No
\end{tabular}

The Boards concluded that information about the financing of business activities should be shown according to the source. The financing section would include nonowner sources of financing and the equity section would display information from owner sources.

\section{What Do The CPA's Think}

Should equity be presented as a section separate from the financing section or should it be included as a category in the financing section?
Yes

$64 \%$
No

$36 \%$

In the Statement of Financial Position, information about discontinued operations would be shown separately from its continuing business and financing activities. 


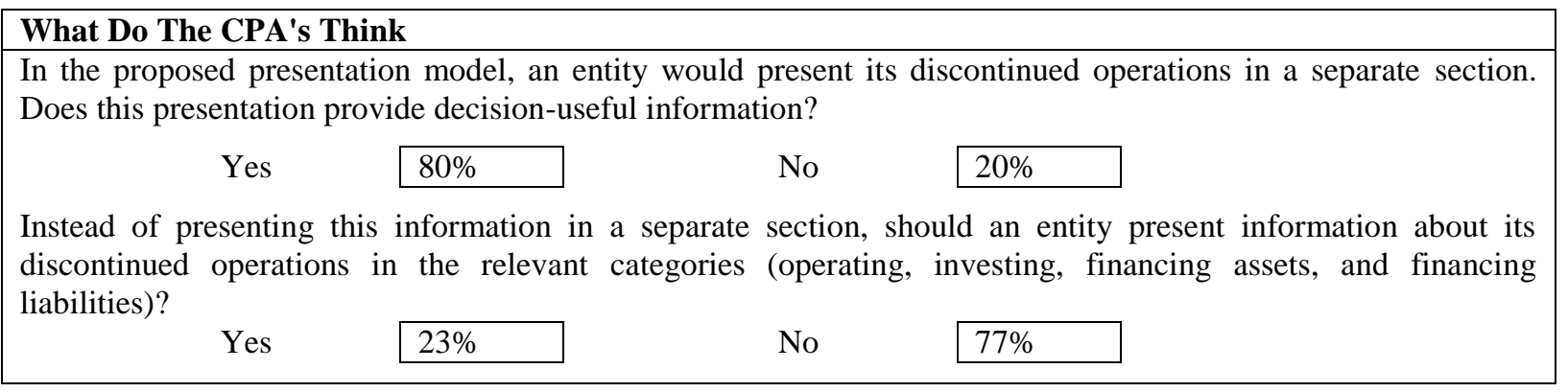

Management would classify its assets and liabilities into the sections and categories in the statement of financial position based upon how management thinks the asset or liability is used within the entity. This classification by management would determine the classification in the statements of comprehensive income and cash flows.

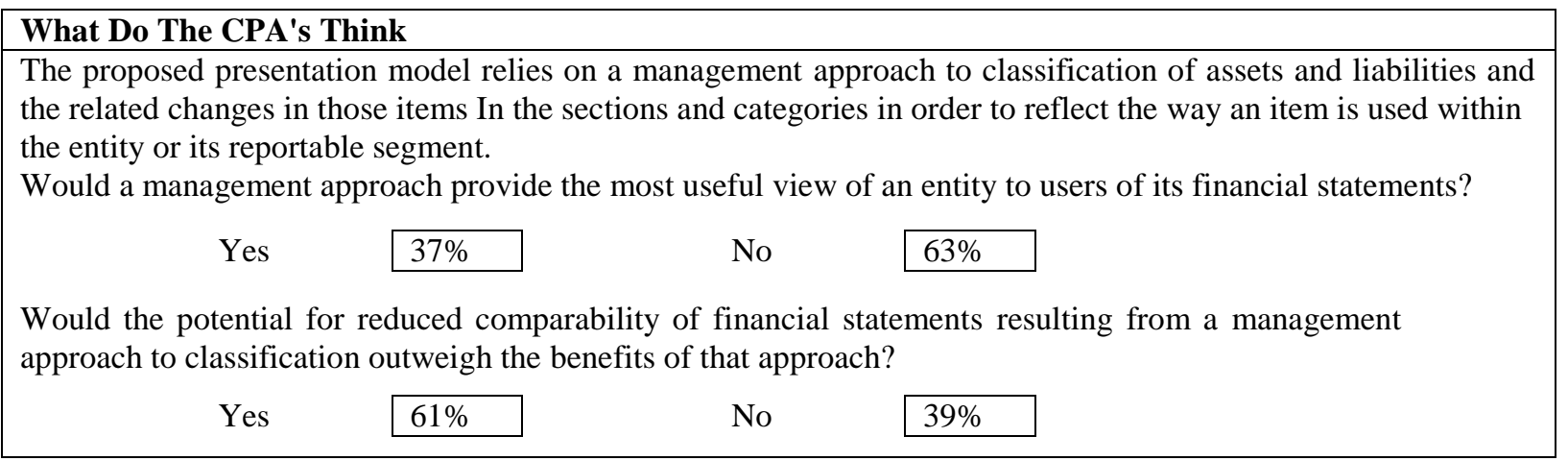

What Do The CPA's Think
The paper proposes that both assets and liabilities should be presented in the business section and in the financing
section of the statement of financial position.
Would this change in presentation coupled with the separation of business and financing activities in the
statements of comprehensive income and cash flows make it easier for users to calculate some key financial
ratios for an entity's business activities or its financing activities?
Yes
$36 \%$

The Discussion Paper states that the business section should include assets and liabilities that management views as part of its continuing business activities of producing goods or providing services with customers, suppliers, and employees.

The operating category should include assets and liabilities that management views as related to the central purpose for which the entity is in business and the investing category should include assets and liabilities that management views as unrelated to the central purpose for which the entity is in business.

\begin{tabular}{|c|c|c|c|c|}
\hline \multicolumn{5}{|c|}{ What Do The CPA's Think } \\
\hline \multicolumn{5}{|c|}{ Are the business section and the operating and investing categories within that section defined appropriately? } \\
\hline Yes & $47 \%$ & No & $53 \%$ & \\
\hline
\end{tabular}

The financing section should include financial assets and financial liabilities that management views as part of the financing of the entity's business and other activities. The liabilities would normally result from capitalraising activities to fund business activities. 


\section{What Do The CPA's Think}

Are the financing section and the financing assets and financing

liabilities categories within that section defined appropriately?

\begin{tabular}{llll} 
Yes & $45 \%$ & No & $55 \%$ \\
\hline
\end{tabular}

Should the financing section be restricted financial liabilities as defined in IFRSs and U.S. GAAP as proposed?

$$
\text { Yes }
$$$$
64 \%
$$

No

$36 \%$

The Discussion Paper proposes the elimination of cash equivalents. These types of securities should be shown as short-term investments and not presented as part of cash in the statement of financial position.

\section{What Do The CPA's Think}

The Discussion Paper proposes that cash equivalents should be presented and classified in a manner similar to other short-term investments, not as part of cash.

Do you agree?

$$
\begin{array}{llll}
\text { Yes } & 54 \% & \text { No } & 46 \% \\
\hline
\end{array}
$$

The Boards required disaggregation of assets and liabilities according to their measurement bases and present them on separate lines in the statement of financial position. For example, securities measured at amortized cost and securities measured at fair value should be shown on separate lines.

\section{What Do The CPA's Think}

An entity should present its similar assets and liabilities that are measured on different bases on separate lines in the statement of financial position. Would this disaggregation provide information that is more decision useful than a presentation that permits line items to include similar assets and liabilities measured on different bases?

\begin{tabular}{llll} 
Yes & No & No & $50 \%$ \\
\hline
\end{tabular}

\section{STATEMENT OF COMPREHENSIVE INCOME}

There is to be only a single Statement of Comprehensive Income (Exhibit 3) of which net income or loss would be a subtotal. Comprehensive income and other comprehensive income would no longer be allowed to be shown in the statement of changes in stockholder's equity.

\section{What Do The CPA's Think}

Should an entity present comprehensive income and its components in a single statement of comprehensive income as proposed?

\begin{tabular}{llll} 
Yes & No & $36 \%$ \\
\hline
\end{tabular}

\section{STATEMENT OF CASH FLOWS}

There are two major changes in the proposed format of the Statement of Cash Flows (Exhibit 4). Firstly, the elimination of cash equivalents and secondly, the entity would use the direct method to present its cash receipts and cash payments. The use of the indirect method would no longer be allowed for the operating activities section of the statement of cash flows. 


\section{What Do The CPA's Think}

The Paper proposes that an entity should use a direct method of presenting cash flows in the statement of cash flows.

Would a direct method of presenting operating cash flows provide information that is decision useful?

$$
\begin{array}{llll}
\text { Yes } & \text { No } & 41 \% \\
\hline
\end{array}
$$

Is a direct method more consistent with the proposed cohesiveness and disaggregation objectives than an indirect method?

Yes $\quad 58 \% \quad$ No $42 \%$

Would the information currently provided using an indirect method to present operating cash flows be provided in the proposed reconciliation schedule?

\begin{tabular}{llll} 
Yes & No & $48 \%$ \\
\hline
\end{tabular}

\section{NEW: A RECONCILIATION SCHEDULE}

A new Reconciliation Schedule, (Exhibit 5), will be presented in the notes to the financial statements. This schedule reconciles cash flows to comprehensive income.

\section{What Do The CPA's Think}

The Paper proposes that an entity should present a schedule in the notes to financial statements that reconciles cash flows to comprehensive income and disaggregates comprehensive income into four components: (a) cash received or paid other than in transactions with owners, (b) accruals other than remeasurements, c)remeasurements that are recurring fair value changes or valuation adjustments, and (d) remeasurements that are not recurring fair value changes or valuation adjustments.

Would the proposed reconciliation schedule increase users' understanding of the amount, timing, and uncertainty of an entity's future cash flows?

Yes

$51 \% \quad$ No

$49 \%$

The proposed financial statements presentation would apply to all entities except not-for-profit entities and nonpublic entities. The Discussion Paper states that the FASB has not considered explicitly whether this model should apply to nonpublic entities.

\section{What Do The CPA's Think}

Do you think the FASB should consider the proposed presentation model to nonpublic entities?

Yes

$$
23 \%
$$

No $77 \%$

\section{CONCLUSION}

The survey clearly shows that the CPA's do not think the objectives of the proposed financial statement presentation would improve the usefulness of the information provided in an entity's financial statements and help users make better decisions. 


\begin{tabular}{|c|c|c|}
\hline \multicolumn{3}{|l|}{$\begin{array}{cc}\text { Long Company } \\
\text { Statement of Financial Position } \\
\text { Proposed Format }\end{array}$} \\
\hline \multirow[b]{3}{*}{$\begin{array}{l}\text { BUSINESS } \\
\text { Operating }\end{array}$} & \multicolumn{2}{|c|}{ As at December 31} \\
\hline & 2009 & 2008 \\
\hline & & \\
\hline \multirow{2}{*}{$\begin{array}{l}\text { Accounts receivable, trade } \\
\text { Less allowance for doubtful accounts }\end{array}$} & 943,050 & 805,550 \\
\hline & $(67,680)$ & $(69,180)$ \\
\hline $\begin{array}{l}\text { Less allowance for doubtful accounts } \\
\text { Accounts receivable, net }\end{array}$ & 875,370 & 736,370 \\
\hline \multirow{2}{*}{$\begin{array}{l}\text { Inventory } \\
\text { Prepaid rent }\end{array}$} & 57,250 & 73,250 \\
\hline & 42,000 & 36,000 \\
\hline \multirow[t]{2}{*}{ Total short-term assets } & 974,620 & 845,620 \\
\hline & $2,378,000$ & $2,258,000$ \\
\hline Less accumulated depreciation & $(1,929,694)$ & $(1,349,847)$ \\
\hline \multirow{2}{*}{$\begin{array}{l}\text { Property, plant and equipment net } \\
\text { Investment in } \mathrm{ABC} \text { Co. }\end{array}$} & 448,306 & 908,153 \\
\hline & 424,800 & 424,000 \\
\hline Investment in $\mathrm{ABC} \mathrm{Co}$. & 873,106 & $1,332,153$ \\
\hline \multirow{2}{*}{$\begin{array}{l}\text { Accounts payable, trade } \\
\text { Wages payable }\end{array}$} & $(49,400)$ & $(43,900)$ \\
\hline & $(35,200)$ & $(17,200)$ \\
\hline $\begin{array}{l}\text { Wages payable } \\
\text { Warranties payable }\end{array}$ & $(35,000)$ & $(30,000)$ \\
\hline \multirow[t]{2}{*}{ Current portion of lease liability } & $(75,131)$ & $(68,301)$ \\
\hline & $(194,731)$ & $(159,401)$ \\
\hline \multirow{2}{*}{$\begin{array}{l}\text { Lease liability } \\
\text { Other long-term liabilities }\end{array}$} & $(173,555)$ & $(248,686)$ \\
\hline & $(50,000)$ & $(50,000)$ \\
\hline Total long-term liabilities & $(223,555)$ & $(298,686)$ \\
\hline \multirow{2}{*}{$\begin{array}{l}\text { Investing } \\
\quad \text { Available-for-sale securities (short-term) }\end{array}$} & $1,429,440$ & $1,719,686$ \\
\hline & 62,000 & 54,000 \\
\hline \multirow[t]{2}{*}{ Investment in XYZ Co. (long-term) } & 685,500 & 683,000 \\
\hline & 747,500 & 737,000 \\
\hline NET BUSINESS ASSETS & $2,176,940$ & $2,456,686$ \\
\hline \multicolumn{3}{|l|}{$\begin{array}{l}\text { FINANCING } \\
\text { Financing assets }\end{array}$} \\
\hline $\begin{array}{l}\text { Financing assets } \\
\text { Cash }\end{array}$ & $2,170,080$ & $1,258,480$ \\
\hline Total financing assets & $2,170,080$ & $1,258,480$ \\
\hline Financing liabilities & & \\
\hline Short-term borrowings & $(400,000)$ & $(400,000)$ \\
\hline Total short-term financing liabilities & $\frac{(17,000)}{(417,000)}$ & $\frac{(9,000)}{(409,000)}$ \\
\hline Long-term borrowings & $(619,000)$ & $(545,000)$ \\
\hline Total financing liabilities & $(1,036,000)$ & $(954,000)$ \\
\hline NET FINANCING ASSETS & $1,134,080$ & 304,480 \\
\hline INCOME TAXES & & \\
\hline Short-term & & \\
\hline $\begin{array}{l}\text { Deferred tax asset } \\
\text { Income taxes payable }\end{array}$ & $\begin{array}{c}15,200 \\
(45828)\end{array}$ & $\begin{array}{c}10,400 \\
(26,686)\end{array}$ \\
\hline Long-term & & $(20,000)$ \\
\hline Deferred tax liability & $(136,000)$ & $(216,000)$ \\
\hline NET INCOME TAX LIABILITY & $(166,628)$ & $(232,286)$ \\
\hline DISCONTINUED OPERATIONS & & \\
\hline Assets held for sale & 162,000 & 162,000 \\
\hline Liabilities related to assets held for sale & $(80,000)$ & $(89,000)$ \\
\hline NET ASSETS HELD FOR SALE & 82,000 & 73,000 \\
\hline NET ASSETS & \begin{tabular}{|l|}
$3,226,392$ \\
\end{tabular} & $2,601,880$ \\
\hline EQUITY & & \\
\hline Share capital & $(1,552,000)$ & $(1,437,000)$ \\
\hline Retained earnings & $(1,761,192)$ & $(1,162,480)$ \\
\hline Accumulated other comprehensive income & 1,800 & $(2,400)$ \\
\hline Treasury Stock & 85,000 & \\
\hline TOTAL EQUITY & $(3,226,392)$ & $(2,601,880)$ \\
\hline Total short-term assets & $3,383,900$ & $2,330,500$ \\
\hline Total long-term assets & $1,558,606$ & $2,015,153$ \\
\hline Total assets & $4,942,506$ & $4,345,653$ \\
\hline Total short-term liabilities & $(737,559)$ & $(684,087)$ \\
\hline Total long-term liabilities & $(978,555)$ & $(1,059,686)$ \\
\hline Total liabilities & $(1,716,114)$ & $(1,743,773)$ \\
\hline
\end{tabular}


Exhibit 3

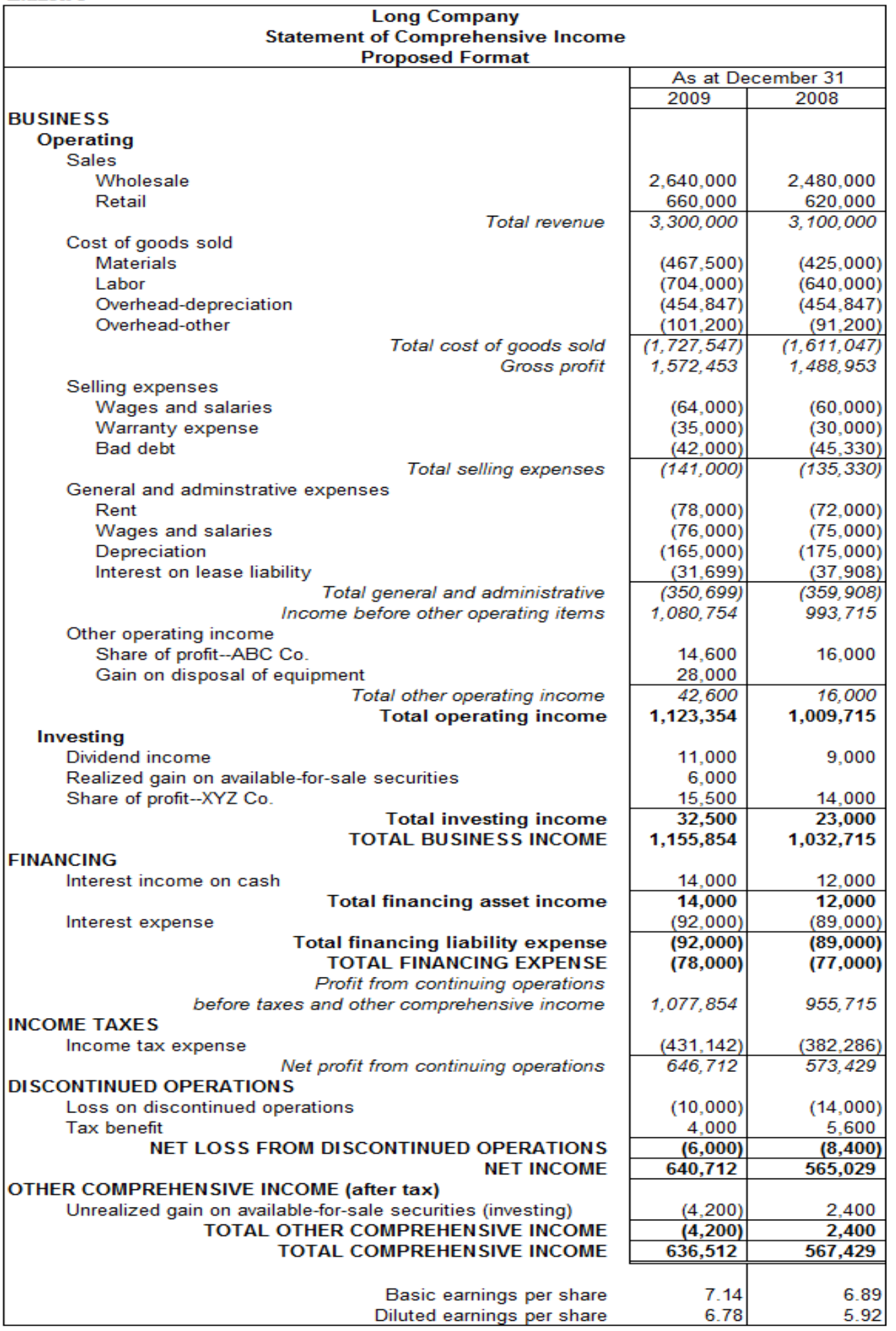




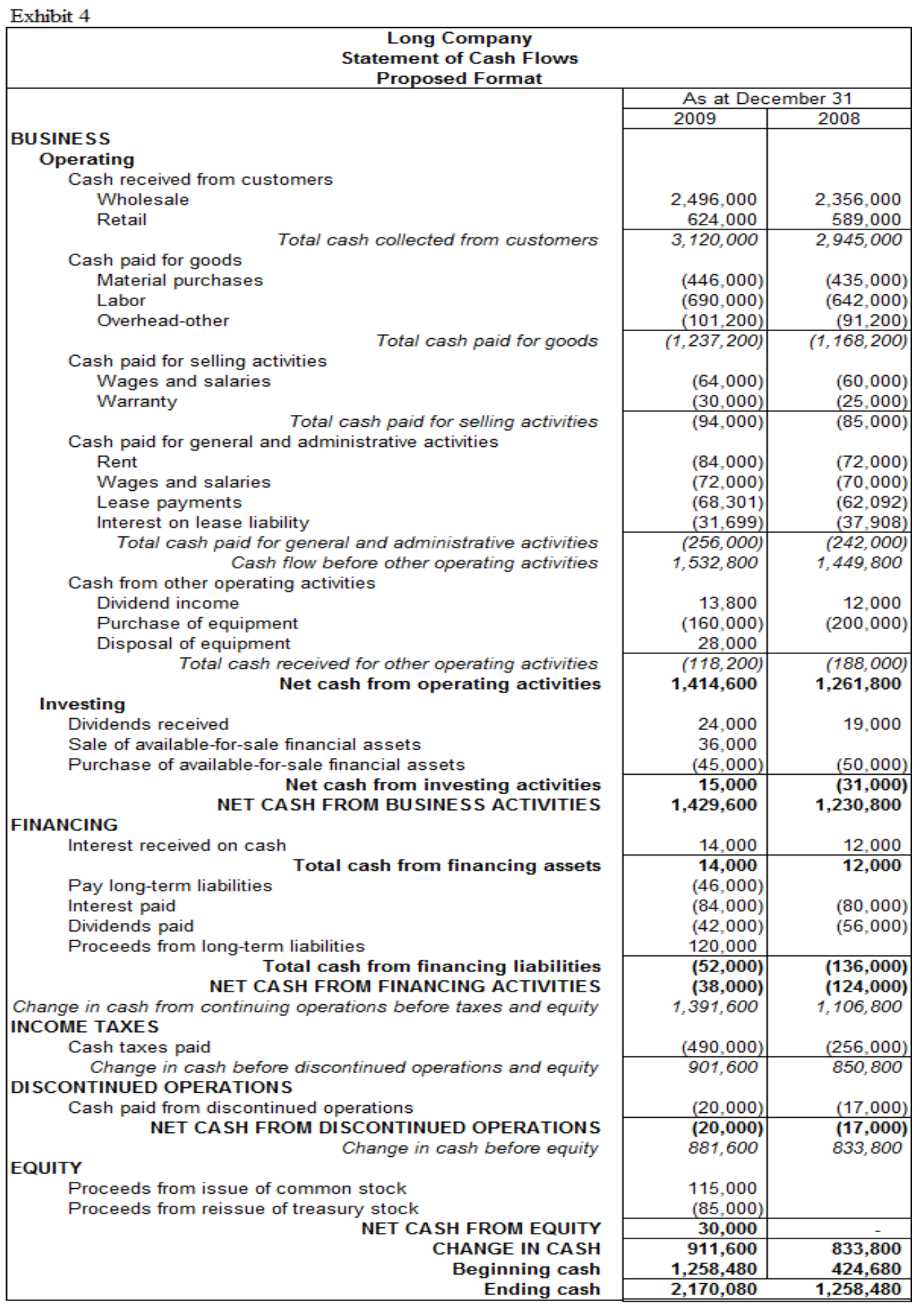




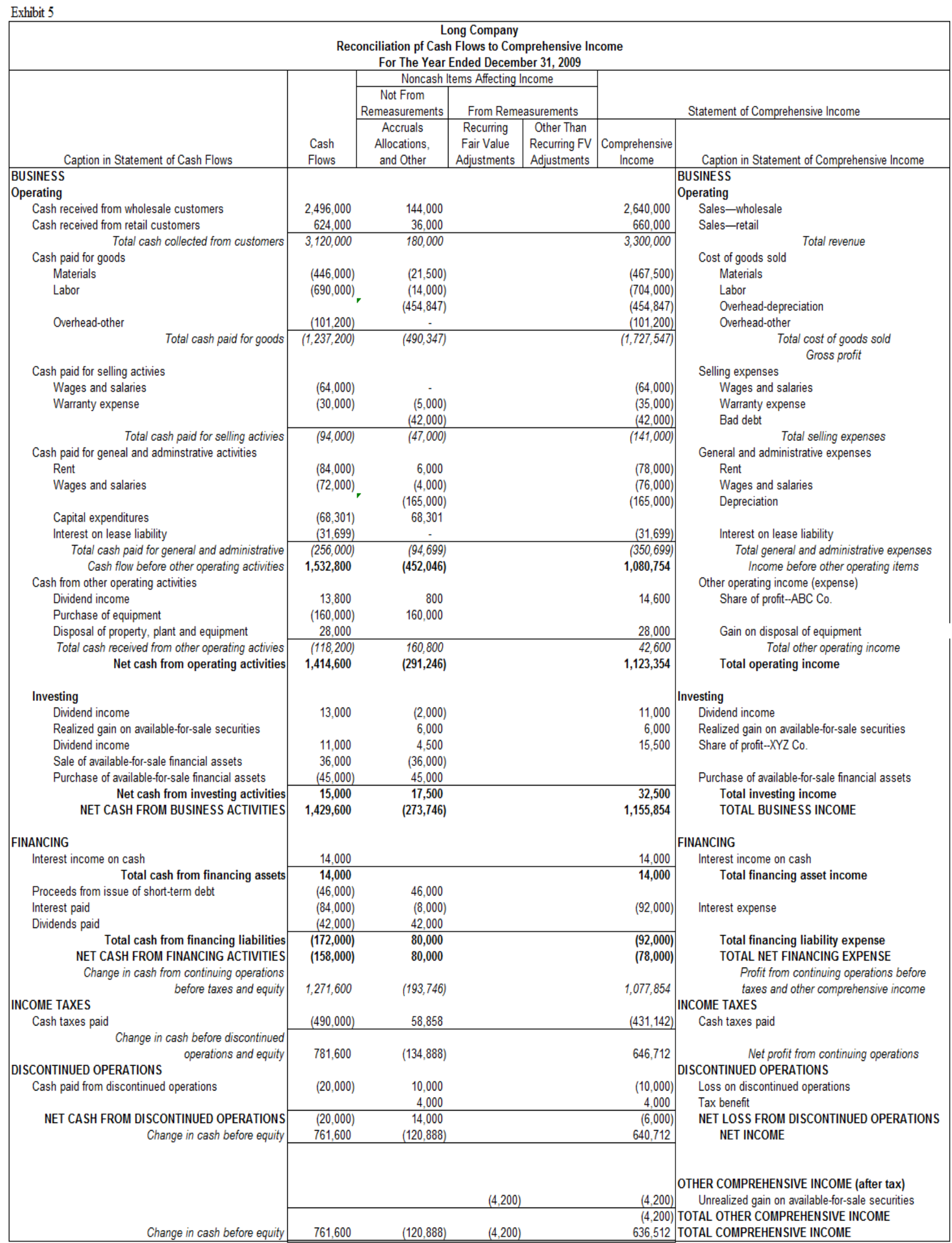




\section{AUTHOR INFORMATION}

Stuart Shough has worked in the private sector for 12 years and has taught accounting for 26 years. He is currently Senior Instructor at the George Dean Johnson, Jr. College of Business and Economics at the University of South Carolina Upstate.

\section{REFERENCES}

Available from author.

\section{NOTES}

